\title{
KAIN PERCA SEBAGAI MEDIA KREASI PKK DI NAGARI SUNGAI ABANG KECAMATAN LUBUK ALUNG
}

\author{
Yulimarni \\ Nofi Rahmanita \\ Prodi Seni Kriya-Fakultas Seni Rupa dan Disain \\ Institut Seni Indonesia Padang Panjang \\ Jl. Bahder Johan. Padang Panjang. Sumatera Barat \\ yulimarni1979@gmail.com \\ nofi.tekstil@gmail.com
}

\begin{abstract}
ABSTRAK
PKK merupakan penggerak dalam membangun, membina dan membentuk keluarga guna mewujudkan kesejahteraan keluarga. Untuk mencapai keluarga bahagia perlu didukung dengan pendidikan dan ketrampilan sesuai dengan program kerja PKK. Kegiatan pengabdian dilakukan bertujuan untuk mendukung program PKK dengan memberikan pelatihan ketrampilan dalam rangka meningkatkan pengetahuan dan apresiasi ibu PKK terhadap produk kain perca, sesuai dengan tema pengabdian "Kain Perca sebagai Media Kreasi PKK Nagari Sungai Abang". Memanfaatkan kain perca, para penggerak PKK dapat membuat dan menghasilkan produk kriya yang kreatif dan inovatif, yang memiliki nilai jual dan dapat meningkatkan pendapatan masyarakat dan kesejahteraan keluarga. Kegiatan pengabdian dilakukan melalui metode ceramah penyuluhan, demontrasi dan praktek atau pelatihan. Hasil dari kegiatan ini adalah bertambahnya pengetahuan ibu PKK tentang manfaat kain perca dan terampil dalam mengolah kain perca sehingga peserta dapat membuat dan menghasilkan produk berupa tas mukena, taplak meja, sarung bantal kursi dan lain sebagainya.
\end{abstract}

Kata kunci : Ketrampilan, kain perca, media, kreasi 


\section{Jurnal Batoboh, Vol 3, No 2, Oktober 2018 \\ Yulimarni, Nofi Rahmanita}

\section{PENDAHULUAN}

Lubuk Alung merupakan salah satu kecamatan yang berada di Kabupaten Padangpariaman, meskipun hanya berstatus kecamatan, Lubuk Alung adalah salah satu pusat pertumbuhan ekonomi terpenting di Kabupaten Padang Pariaman dan menjadi kota penyangga bagi wilayah Palapa (Padang - Lubuk Alung - Pariaman). Awalnya kecamatan Lubuk Alung adalah salah satu kecamatan yang cukup luas di Kabupaten Padang Pariaman dan memiliki satu nagari, yaitu nagari Lubuk Alung. Setelah pemekaran daerah Sintuk Toboh Gadang menjadi kecamatan tersendiri, kecamatan Lubuk Alung dimekarkan menjadi lima nagari yaitu: Lubuk Alung, Pasielaweh, Pungguang Kasiak, Sikabu, dan AieTajun. Tahun 2016 bertambah 4 nagari yaitu Balah Hilia, Sungai Abang, Singguliang, dan Salibutan.

Nagari Sungai Abang adalah nagari yang menempati posisi yang sangat strategis yakni dilintasi jalur utama lintas Sumatera jalan Padang - Bukittinggi. Di nagari ini berdiri sekolah-sekolah favorit seperti SMPN 01, SMA N 01, SMK dan juga fasilitas umum lainnya seperti puskesmas dan sebuah lapangan hijau yang selalu ramai dengan kegiatan setiap sore. Didukung kondisi lingkungan yang sangat baik tersebut, telah membawa dampak positif bagi masyarakat nagari Sungai Abang untuk selalu memajukan wilayahn- ya, karena majunya sebuah nagari jelas tidak terlepas dari peran aktif masyarakat.

Salah satu kelompok yang aktif untuk kemajuan dan kemaslahatan nagarinya adalah kelompok PKK (Pemberdayaan kesejahteraan keluarga). PKK merupakan gerakan yang tumbuh dari bawah oleh perempuan sebagai penggerak dalam membangun, membina dan membentuk keluarga guna mewujudkan kesejahteraan keluarga, (Ismail, 2014: ). Untuk mewujudkan hal tersebut PKK memiliki 10 program pokok, salah satunya adalahprogram pendidikan dan ketrampilan.

Secara umum potensi sumberdaya manusia di nagari Sungai Abang memiliki usia produktif. Hanya saja potensi tersebut belum termaksimalkan dengan baik. Sebagai salah satu upaya PKK untuk membawa masyarakat tersebut pada solusi kesejahteraan yang lebih baik adalah dengan menciptakan sebuah wadah kegiatan yang positif melalui pembekalan berbagai keterampilan.

Keterampilan atau kerajinan kain perca merupakan salah satu kerajinan yang menjadi bagian dari dunia jahit-menjahit. Kerajinan ini dibuat dengan menggunakan bahan yang tergolong limbah yaitu bermacammacam kain perca. Kain perca digunakan untuk membuat sebuah karya kerajinan yang indah dan bahkan memiliki nilai seni tinggi. Caranya adalah dengan memotong-motong beragam kain sisa menjadi satu kesatuan se- 


\section{Jurnal Batoboh, Vol 3, No 2, Oktober 2018 \\ Yulimarni, Nofi Rahmanita}

hingga terlahir berbagai bentuk, kemudian menggabungkan potongan-potongan tersebut dengan menjahitnya kembali. Tentunya perpaduan warna dan pola kain juga harus diperhatikan agar bisa tercipta sebuah kerajinan perca yang indah (Eka Yunita: 2011).

Kerajinan kain perca saat ini sudah menjadi salah satu kerajinan yang paling dikagumi dan diminati oleh banyak orang Indonesia, bahkan juga di seluruh dunia. Kerajinan kain perca telah menjadi salah satu trend baru yang disebabkan oleh adanya sentuhansentuhan kontemporer yang diberikan pada kreasi-kreasi baru yang tercipta.

Kerajinan kain perca ini dapat ditemukan dalam beragam jenis kreasi serta pola yang indah dan bernilai seni tinggi seperti; bed cover, taplak meja cantik, baju, tas, sajadah, hiasan dinding, dan lain sebagainya.

Seni kerajinan kain perca juga merupakan bagian dari seni kriya, hal ini disebabkan seni kerajinan kain perca merupakan hasil budidaya manusia dalam memenuhi kebutuhan akan benda. Seni kriya yang beragam jenis serta digeluti sepanjang masa.

Seni kriya sebagai budidaya manusia di dalam memenuhi akan benda terus berlanjut hingga kini. Saat manusia masih bertaraf sederhana, seni kriya menduduki tempat yang amat penting dan sangat dihandalkan (Suyanto, 2016:1 ). Oleh sebab itu melalui pelatihan ini ibu-ibu PKK bisa mengembangkan po- tensi yang ada dalam diri mereka, sehingga dapat menambah penghasilan dalam rangka meningkatkan perekonomian keluarga, meningkatkan kualitas hidup, dan menciptakan lapangan kerja khususnya seni kain perca.

Kriya sebagai produk yang dihasilkan dalam suatu proses kegiatan dengan atau tanpa bantuan mesin, bernilai estetik, kegunaan dan dapat diproduksi dalam jumlah tertentu untuk memanfaatkan ekonomik (Yusuf Effendi dalam Suyanto: 2016). Oleh sebab itu kerajinan kain perca yang merupakan bagian seni kriya ini menjadi salah satu kerajinan yang diminati oleh ibu rumah tangga dan remaja putri.

Sehubungan dengan kegiatan tersebut ada beberapa permasalahan yang dapat diidentifikasi yaitu:

1. Umumnya masyarakat khususnya ibu-ibu PKK memiliki potensi serta kemauan yang dapat dikembangkan dalam pelatihan, namun masih kurangnya pengetahuan dan pemahaman mereka khususnya tentang keberadaan dan manfaat yang diperoleh dari limbah kain perca.

2. Pengalaman, pengetahuan, dan keterampilan ibu-ibu PKK dalam membuat produk yang kreatif dan inovatif perlu dibina, dengan memberi semangat agar mereka nantinya mampu membuat produk yang kreatif dan inovatif dari kain perca.

3. Kelompok umumnya belum pernah men- 


\section{Jurnal Batoboh, Vol 3, No 2, Oktober 2018 \\ Yulimarni, Nofi Rahmanita}

dapatkan pelatihan ketrampilan khususnya mengolah kain perca menjadi produk kriya.

Berdasarkan haltersebut di atas perlu kiranya diberi pelatihan sebagai wujud dukungan dari program PKK khususnya di bidang pendidikan dan ketrampilan. Bentuk ketrampilan yang diajarkan kepada ibu PKK nagari Sungai Abang terkait dengan pemanfaatan limbah kain perca. Kain perca sebagai media kreasi merupakan salah satu upaya dalam mengurangi limbah di lingkungan sekitarnya. Kain perca berupa sisa potongan-potongan kain yang dihasilkan dari para penjahit yang ada di sekitar Lubuk Alung, dapat diolah dan dikreasikan dengan berbagai teknik sehingga dapat menghasilkan produk yang bermanfaat untuk kemaslahatan keluarga. Hal tersebut sangat cocok dikembangkan di lingkungan ibu-ibu, karena terkait dengan teknik jahit menjahit.

Metode yang digunakan untuk mencapai target dalam pelatihan adalah sebagai berikut:

1. Metode ceramah: pelaksanaannya, intruktur dan tim mensosialisasikan program kegiatan, penyuluhan tentang pentingnya penguasaan keterampilan sebagai bentuk kebutuhan bagi pengembangan diri, khususnya bagi kaum ibu/wanita baik secara individual maupun untuk kepentingan kelompok, penjelasan tentang dasar-dasar desain, agar terciptanya karya yang kreatif dan inovatif sehingga lay- ak dan diminati oleh konsumen, penjelasan tentang tahap pembuatan produk kriya; membuat desain, membuat pola, proses menjahit, dan pengemasan.

2. Metode Demonstrasi: pelaksanaannya, instruktur dan tim mendemonstrasikan bagaimana cara membuat desain yang baik, pembuatan pola, pemindahan pola, proses menjahit sehingga menjadi produk.

3. Praktek atau pelatihan: pelaksanaanya, para peserta pelatihan mempraktekan langsung mulai pembuatan desain, pola dan mewujudkan ke dalam bentuk produk, selama praktek dilakukan pendampingan langsung mulai dari tahap pembuatan desain sampai pada tahap pengemasan. Pendampingan dilakukan oleh tim secara bersama.

Metode dilakukan mulai dari awal sampai akhir, berurutan secara teknis, sehingga peserta pelatihan benar-benar menguasai keterampilan tersebut dengan baik.

\section{HASIL DAN PEMBAHASAN}

Kegiatan pengabdian masyarakat diberikan kepada ibu-ibu PKK yang ada di Nagari Sungai Abang Kecamatan Lubuk Alung. Pelatihan diawali dengan koordinasi dengan ketua PKK nagari Sungai Abang sebagai mitra, mengenai hal-hal yang terkait dengan kegiatan pengabdian. Kemudian mensosialisasikan program kegiatan kepada peserta pelatihan sehingga peserta mengerti maksud 


\section{Jurnal Batoboh, Vol 3, No 2, Oktober 2018 \\ Yulimarni, Nofi Rahmanita}

dan tujuan dilaksanakannya kegiatan pengabdian dan selanjutnya menjelaskan langkahlangkah atau tahapan yang akan dilakukan selama pelatihan. Tahap selanjutkan melakukan survey untuk pengadaan bahan dan alat yang dibutuhkan selama pelatihan.

Bahan yang perlu disiapkan dalam pelatihan adalah kain perca sebagai bahan dasar yang dibawa sendiri oleh peserta, kemudian karton untuk pola, kertas HVS untuk pembuatan desain, benang, busa pelapis, pita, lem, dan bahan pendukung lainnya yang dapat memperindah sebuah produk. Dalam pelatihan juga diperlukan beberapa alat di antaranya: pensil, penggaris, meteran, rader, gunting, jarum jahit tangan, jarum mesin dan alat pendukung lainnya yang dapat membantu kelancaran selama kegiatan.

Pada tahap selanjutnya dilakukan demonstrasi, praktek dan pendampingan. Pada tahap ini diawali pembuatan desain. Desain yang di maksud dalam hal ini bukan saja bentuk secara global, akan tetapi juga bagaimana bentuk komposisi potongan kain perca yang memiliki beragam warna dan motif. Desain yang sudah dibuat kemudian dituangkan pada media karton dengan skala 1:1, setelah itu karton digunting sesuai dengan pola desain. Dan ini akan digunakan sebagai pedoman atau pola dalam pemotongan bahan perca. Pola yang sudah dibuat kemudian digunakan sebagai mal (cetakan) dalam pe-

motongan bahan kain perca. Pola dicetak ke kain perca, kemudian kain digunting sesuai dengan pola.

Langkah selanjutnya adalah menjahit dalam rangka menyatukan setiap elemen sehingga menghasilkan bentuk yang bernilai sesuai dengan fungsinya. Ada dua teknik jahit yang digunakan dalam kegiatan ini yaitu menjahit secara manual menggunakan jarum tangan seperti pembuatan bros jilbab. Dan menjahit menggunakan mesin untuk pembuatan bucket bag, tote bag dan sarung bantal kursi, kemudian dilanjutkan pada tahap pengemasan. Kegiatan yang dilakukan pada tahap pengemasan adalah mengemas produk yang sudah jadi ke dalam plastik agar produk tidak kotor. Pengemasan dapat dilakukan setelah pemasangan aksesoris dan merapikan semua sisa-sisa benang.

Berikut beberapa proses kegiatan dan hasil kreasi ibu PKK dari kain perca:

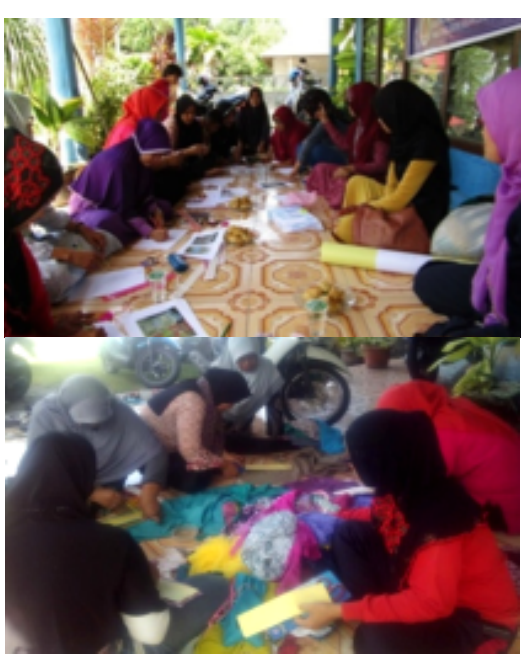

Gambar 1.

Proses pembuatan desain Foto: Yuli, 2017 


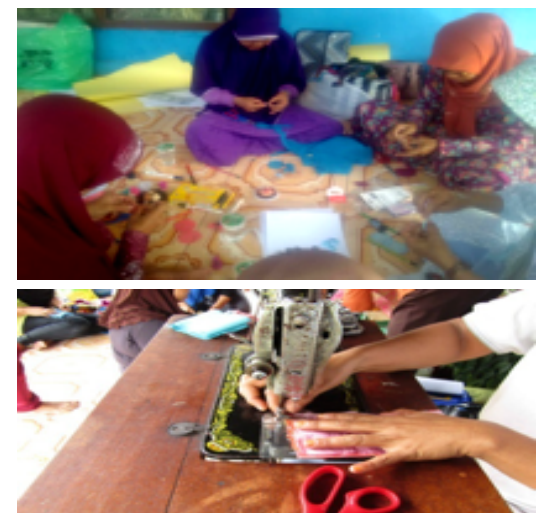

Gambar. 2

Proses pemotongan kain perca dan menjahit (Foto; dokumentasi, Yuli, 2017)

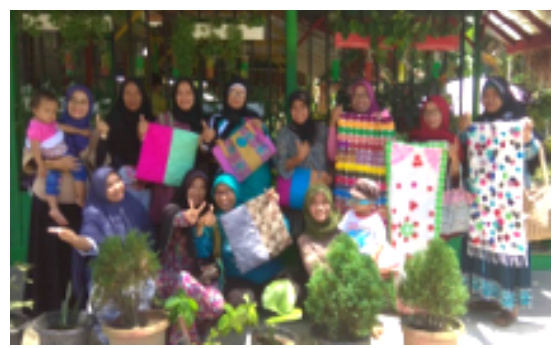

Gambar 3.

Hasil kreasi ibu PKK dari media kain perca (Foto; dokumentasi, Yuli, 2017)

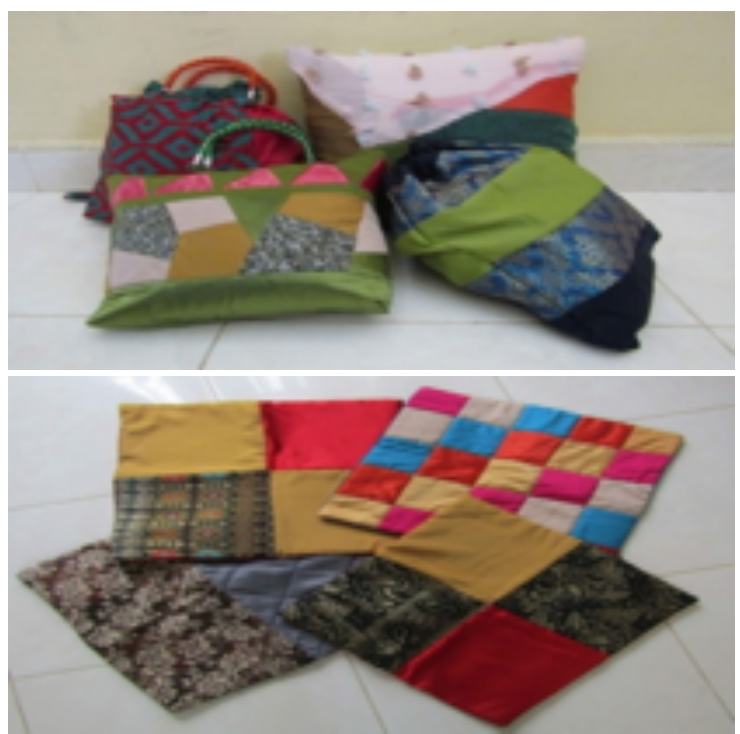

Gambar 4.

Hasil kreasi ibu PKK dari media kain perca (Foto; dokumentasi, Yuli, 2017)

\section{SIMPULAN}

Berdasarkan permasalahan dan proses kegiatan pelatihan yang telah dilakukan bersama ibu PKK di Nagari Sungai Abang, maka dapat disimpulkan bahwa:

1. Kegiatan pelatihan ketrampilan "kain perca sebagai media kreasi" telah membantu ibu PKK di dalam menjalankan salah satu program pokok PKK di bidang pendidikan dan ketrampilan.

2. Ibu-ibu PKK nagari Sungai Abang sangat antusias mengikuti kegiatan, hal ini terlihat dari kesungguhan dan ketekunan ibu-ibu PKK selama kegiatan berlangsung dan karyakarya yang mereka buat.

3. Kegiatan pelatihan ini telah dapat meningkatkan pengetahuan dan kreativitas ibu-ibu PKK terhadap ketrampilan berkreasi dengan limbah kain perca, sehingga mereka telah mampu membuat produk yang memiliki nilai jual. 


\section{KEPUSTAKAAN}

Ambar Teguh Sulistiyani. 2017. "Proses

Pemberdayaan Masyarakat Desa

Sitimulyo, Kecamatan Piyungan,

Kabupaten Bantul dalam Pemben

tukan Kelompok Pengelola Sampah

Mandiri', Indonesian Journal of

Community Engagement Vol. 02,

No. 02, UGM Yogyakarta.

Eka Yunita. 2011. Patcwork dan Qiulting

untuk Pemula (Berkreasi dengan

Kain Perca), Jakarta: Demedia

Pustaka.

Hery Suherno. 2004. Desain Motif. Pustaka

Pembangunan Swadaya Nusantara.

Jakarta

S. Suyanto. 2016. "Seni Kriya: Teknik dan

Kreasi” Jurnal Seni Rupa STSI

Surakarta

Sherly A. Suherman. 2012. Kreasi Tas Cantik

Dari Kertas Dan Kain, Jakarta: Dunia

Kreasi.

http://www.p2kp.org, Winda Muriani

Panjaitan, 2011, Tantangan Dan

Peransuasi Perempuan Dalam

Pembangunan, (Artikel), didownload

tanggal 6 April 2017. 